\title{
Peranan Asam Klorogenat Tanaman Kopi terhadap Penurunan Kadar Asam Urat dan Beban Oksidatif
}

\author{
Anna Maria Dewajanti \\ Departemen Biokimia Fakultas Kedokteran dan Ilmu Kesehatan Universitas Kristen Krida \\ Wacana \\ Alamat Korespondensi: anna.dewajanthi@ukrida.ac.id
}

\begin{abstract}
Abstrak
Tanaman kopi termasuk dalam golongan familia Rubiaceae, yang merupakan tumbuhan tropis yang tumbuh di lereng gunung. Selain mengandung senyawa kafein, kopi juga mengandung polifenol yang sangat tinggi, yaitu dalam bentuk caffeoylquinic acids (CQAs), feruloylquinic acids (FQAs), dan dicaffe oylquinic acids (diCQAs) serta asam klorogenat (chlorogenic acid). Di antara senyawa polifenol tersebut, yang paling banyak terdapat di dalam kopi adalah asam klorogenat. Senyawa ini memiliki efek farmakologi sebagai antioksidan, sehingga dapat menurunkan beban oksidatif dalam tubuh, dan memiliki kemampuan menghambat aktivitas enzim xantin oksidase, sehingga dapat menurunkan kadar asam urat dalam darah penderita hiperurisemia.
\end{abstract}

Kata kunci: asam klorogenat, kadar asam urat, kafein, kopi

\section{The Role of Chlorogenic Acid of Coffee Plants in Lowering Uric Acid Levels and Oxidative Stress}

\begin{abstract}
Coffee plants which belong to family Rubiaceae is a tropical plant that grows on the slopes of the mountains. Besides caffeine, coffee also contains very high polyphenols, namely caffeoylquinic acids $(C Q A s)$, feruloylquinic acids (FQAs), dicaffe oylquinic acids (diCQAs) and chlorogenic acid. Among the polyphenol compounds, the most abundant in coffee is chlorogenic acid. This compound has a pharmacological effect as an antioxidant, so that it can reduce the oxidative burden in the body. In addition, chlorogenic acid has the ability to inhibit xanthine oxidase activity, thus can reduce uric acid levels in the blood of patients with hyperuricemia.
\end{abstract}

Keywords: acid levels, acid levels, caffein, chlorogenic acid, coffee, uric

\section{Pendahuluan}

Tanaman kopi termasuk dalam golongan familia Rubiaceae, yang mempunyai 500 macam genus dan lebih dari 6.000 spesies. ${ }^{1}$ Kopi merupakan tumbuhan tropis yang tumbuh di lereng gunung, di daerah dengan ketinggian $1.000-2.100 \mathrm{~m}$ di atas permukaan laut. ${ }^{1}$ Semakin tinggi lokasi perkebunan kopi, cita rasa biji kopi yang dihasilkan semakin baik. ${ }^{1}$ Salah satu unsur yang sangat penting pada biji kopi yaitu kafein, dimana unsur ini dapat berfungsi sebagai stimulan dan merupakan faktor yang menentukan rasa. $^{2}$ Kafein merupakan suatu alkaloid dari metil xantin yaitu 1,3,7 trimetil xantin. ${ }^{2}$ Selain mengandung senyawa kafein, kopi juga mengandung polifenol yang sangat tinggi, yaitu dalam bentuk caffeoylquinic acids (CQAs), feruloylquinic acids (FQAs), dan dicaffe oylquinic acids (diCQAs), serta chlorogenic acid. Di antara senyawa polifenol yang paling 
banyak terdapat di dalam kopi adalah asam klorogenat (chlorogenic acid) ${ }^{2,3}$ Hasil penelitian menyatakan bahwa asam klorogenat merupakan salah satu antioksidan poten ${ }^{3,4}$ dari senyawa fenolik yang mampu menghambat aktivitas xantin oksidase sehingga dapat menurunkan kadar asam urat serum pada penderita hiperurisemia. ${ }^{5-7}$

Banyak studi yang meneliti efek konsumsi kopi terhadap berbagai kondisi medis tertentu. Efek positif dan negatif kopi terhadap kesehatan masih diperdebatkan. Beberapa efek positif tersebut antara lain menurunkan risiko penyakit alzheimer, parkinson, diabetes melitus tipe 2, sirosis hati, serta menurunkan kadar asam urat darah. ${ }^{5}$ Efek negatif kopi antara lain mengganggu absorbsi besi sehingga menyebabkan anemia defisiensi besi, ulkus peptikum, esofagitis erosif, dan gastroesofageal refluks. ${ }^{8}$ Hasil studi di Jepang menunjukkan bahwa peminum lima gelas atau lebih kopi per hari memiliki kadar asam urat yang lebih rendah dibandingkan dengan peminum satu gelas atau kurang kopi perhari. ${ }^{3,9}$ Penulisan ini dibuat untuk menambah pengetahuan tentang peranan asam klorogenat yang terdapat di dalam tanaman, khususnya biji kopi, terhadap kadar asam urat darah dan penurunan beban oksidatif.

\section{Kopi}

Tanaman kopi termasuk dalam golongan family Rubiaceae. Di Indonesia dikenal dua jenis kopi, yaitu kopi Robusta (Coffea canephora) dan kopi arabika (Coffea arabica). Dari hasil penelitian diketahui bahwa kadar asam klorogenat dalam biji kopi Arabika adalah $7,73 \% .^{10}$

Kopi mengandung senyawa kafein, asam palmitat, asam linoleat, dan asam stearat. Selain itu, kopi juga mengandung polifenol yang sangat tinggi. Polifenol di dalam kopi sangat kaya dengan caffeoylquinic acids (CQAs), feruloylquinic acids (FQAs), dicaffe oylquinic acids (diCQAs), serta asam klorogenat. Di antara senyawa polifenol yang paling banyak terdapat di dalam kopi adalah asam klorogenat. ${ }^{2,3}$

Kafein dapat menyebabkan peningkatan tekanan darah sehingga dapat membahayakan penderita penyakit jantung dan tekanan darah tinggi. ${ }^{3}$ Meskipun masih kontroversi mengenai manfaat ataupun risiko mengonsumsi kopi, hasil penelitian khusus epidemiologi dan meta- analisis membuktikan bahwa konsumsi kopi tidak menyebabkan risiko kematian. ${ }^{11}$

Kafein mampu menimbulkan peningkatan tekanan darah secara akut dengan memblokir reseptor adenosin yang berfungsi sebagai vasodilator, dan akan meningkatkan norepinefrin (NE) plasma. ${ }^{12,13}$ Dari sebuah studi terhadap kafein yang dilakukan di Polandia, diketahui bahwa mengkonsumsi kafein sama dengan meminum kopi sebanyak 2 atau 3 gelas dapat menyebabkan peningkatan tekanan darah akut. ${ }^{14}$ Namun, ukuran respons pressor yang ditimbulkan oleh kafein bervariasi antara studi dan individu, dari $3 / 4 \mathrm{ke}$ $15 / 13 \mathrm{mmHg}$ dan cenderung lebih besar pada penderita hipertensi. ${ }^{14}$ Puncak dari efek kafein dalam meningkatkan tekanan darah adalah satu jam setelah mengonsumsi kafein, lalu akan kembali ke awal semula setelah empat jam. ${ }^{14}$

\section{Asam Klorogenat (Chlorogenic acid)}

Asam klorogenat merupakan komponen fenolik utama di dalam kopi ${ }^{2,3}$ Struktur molekul asam klorogenat dapat dilihat pada Gambar 1. Hasil penelitian menyatakan bahwa asam klorogenat merupakan salah satu antioksidan poten $^{3,4}$ dari senyawa fenolik yang mampu menghambat aktivitas xantin oksidase sehingga dapat menurunkan kadar asam urat serum pada penderita hiperurisemia. ${ }^{5-7}$ Dari penelitian yang telah dilakukan terhadap tanaman kopi, diperoleh adanya penurunan kadar malondialdehida pada tikus yang hiperurisemia. ${ }^{15}$ Malondialdehida adalah produk dari peroksidasi lipid yang terjadi karena tingginya beban oksidatif pada penderita hiperurisemia. ${ }^{16}$

Asam klorogenat termasuk keluarga dari ester yang terbentuk dari gabungan asam kuinat dan beberapa asam trans-sinamat, umumnya kafein, pcoumaric, dan asam ferulat. ${ }^{18}$ Asam klorogenat adalah suatu senyawa yang termasuk ke dalam komponen fenolik, mempunyai sifat yang larut di dalam air. ${ }^{19}$ Subgrup utama dari isomer asamklorogenat pada kopi adalahcaffeoylquinicacid (CQA), feruloylquinicacid (FQA), dicaffeoylquinicacid (diCQA), dan p-couma-roylquinicacid ( $\mathrm{p}$ CQA) pada jumlah yang lebih kecil. ${ }^{19}$ 


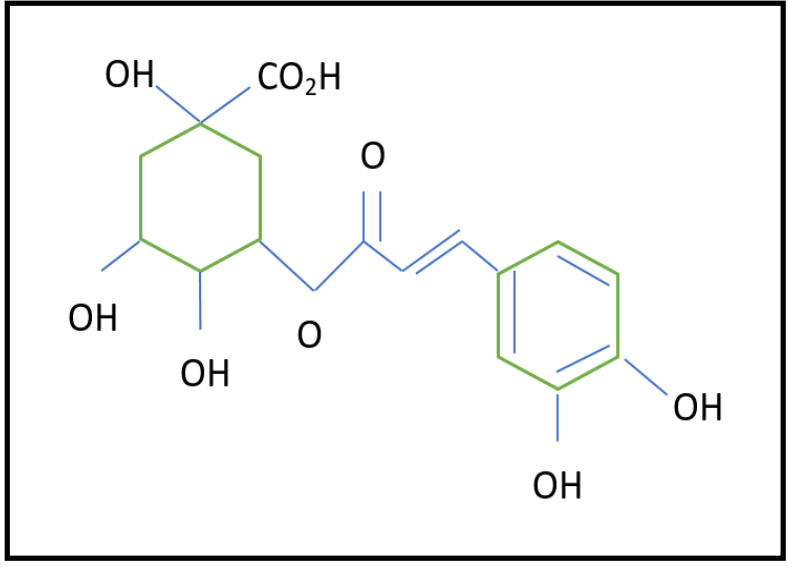

Gambar 1. Struktur Molekul Asam Klorogenat (diadaptasi dari Crozier A, et al. 2006) $^{17}$

Analisis Asam Klorogenat secara kuantitatif dapat dilakukan dengan menggunakan instrumen HPLC $^{20}$ dan spektrofotometer pada panjang gelombang 200-500 nm pada suhu kamar. Didapatkan wilayah asam klorogenat memiliki dua titik maksimum yaitu pada puncak pertama di panjang gelombang $217 \mathrm{~nm}$ dengan bahu di 240 $\mathrm{nm}$, dan puncak kedua pada panjang gelombang $324 \mathrm{~nm}$ dengan bahu di $296 \mathrm{~nm}^{21}$

\section{Efek Farmakologi Asam Klorogenat}

Beberapa Penelitian telah dilakukan untuk melihat efek farmakologi asam klorogenat, salah satu di antaranya adalah menurunkan kadar asam urat darah pada penderita hiperurisemia. ${ }^{5-7}$ Hiperurisemia didefinisikan sebagai kadar asam urat serum lebih dari $7 \mathrm{mg} / \mathrm{dL}$ pada laki-laki dan lebih dari $6 \mathrm{mg} / \mathrm{dL}$ pada wanita. ${ }^{22}$ Hiperurisemia terjadi akibat peningkatan produksi asam urat atau penurunan ekskresi asam urat atau sering merupakan kombinasi keduanya. ${ }^{22}$ Hiperurisemia akibat peningkatan produksi asam urat biasanya disebabkan oleh diet tinggi purin (eksogen), seperti aging merah, kacangkacangan, ataupun proses endogen (pemecahan asam nukleat yang berlebihan). ${ }^{22}$

Tubuh menyediakan $85 \%$ senyawa purin untuk kebutuhan setiap hari. Ini berarti bahwa kebutuhan purin dari makanan hanya sekitar $15 \% .{ }^{23}$ Pada keadaan normal, akan terjadi keseimbangan antara pembentukan dan pemecahan nukleotida purin. Pemecahan nukleotida purin menghasilkan asam urat yang tidak larut. ${ }^{23}$

Sampai saat ini obat yang sering digunakan untuk menurunkan kadar asam urat adalah allopurinol. ${ }^{16}$ Mekanisme kerja allopurinol dengan cara menghambat enzim xantin oksidase, yaitu enzim yang bertanggung jawab untuk merombak senyawa purin (hipoxatin dan xantin) menjadi asam urat. ${ }^{16}$ Struktur kimia allopurinol sangat mirip dengan xantin sehingga enzim xantin oksidase bekerja pada zat tersebut, akibatnya perombakan xantin menjadi asam urat juga menurun. ${ }^{16}$ Proses pembentukan asam urat dapat dilihat pada Gambar 2.

Pembentukan purin memerlukan molekul ribosa-5P (phosphate) dan ATP (Adenosine Triphosfate), yang akan bereaksi membentuk PRPP (5-phosphoribosil pyro phosphate). Dalam reaksi ini memerlukan ion Mg2+ (magnesium) sebagai aktivator. ${ }^{16}$ Selain itu pembentukan purin memelukan glutamin yang akan bereaksi dengan PRPP membentuk 5-fosforibosilamin, asam amino glutamat, dan profosfat. Asam amino glisin dan tetra hidrofolat (FH4) juga diperlukan dalam biosintesis purin. ${ }^{16}$

Derivat purin yang pertama berupa IMP (inosin monophosphate $=$ inosinic acid) yaitu derivat hipoxantin. Sedangkan derivat purin lainnya, yaitu AMP (Adenosine monophosphate) dan GMP (Guanosine Monophosphate) diturunkan dari IMP (Inosine Monophosphate) (Gambar 3). ${ }^{23}$

Pada manusia hasil akhir katabolisme purin adalah asam urat. Sebagian mamalia (tidak termasuk manusia) dapat mengoksidasi asam urat menggunakan enzim urikase menjadi allantoin, yang selanjutnya dapat didegradasi menjadi urea dan amonia. ${ }^{16,23}$ Tahapan reaksi pembentukan asam urat dapat dilihat pada Gambar 2. Hipoxantin akan dioksidasi oleh enzim xantin oksidase membentuk xantin, yang selanjutnya akan dioksidasi kembali oleh enzim yang sama menjadi asam urat, yang merupakan produk akhir dari proses degradasi purin pada manusia. Asam urat akan diekskresikan ke dalam urin (Gambar 3). ${ }^{16,23}$

Enzim xanthin oksidase (XO) adalah enzim yang mengandung molybdenum dan merupakan enzim kunci dalam proses katabolisme purin. Enzim XO mengkatalisis oksidasi hipoxantin menjadi xantin dan selanjutnya menjadi asam urat. Oksigen selama proses oksidasi hipoxantin dan xantin bertindak sebagai akseptor elektron dan menghasilkan radikal superoksida dan hidrogen peroksida, yang merupakan reactive oxygen species (ROS). ${ }^{16,23}$ Semakin banyak molekul purin 
yang dikatabolisme di dalam tubuh, maka akan semakin tinggi kadar asam urat dan semakin besar beban oksidatif yang ditimbulkan. Tingginya ROS dapat menyebabkan terjadinya oksidasi dari berbagai molekul dalam tubuh, salah satunya peroksidasi lipid. Hasil dari peroksidasi lipid merupakan senyawa aldehid, antara lain malondialdehid (MDA). Dengan menghambat XO dapat menurunkan kadar asam urat dan produksi ROS sehingga menghasilkan efek antihiperurisemia. ${ }^{16}$

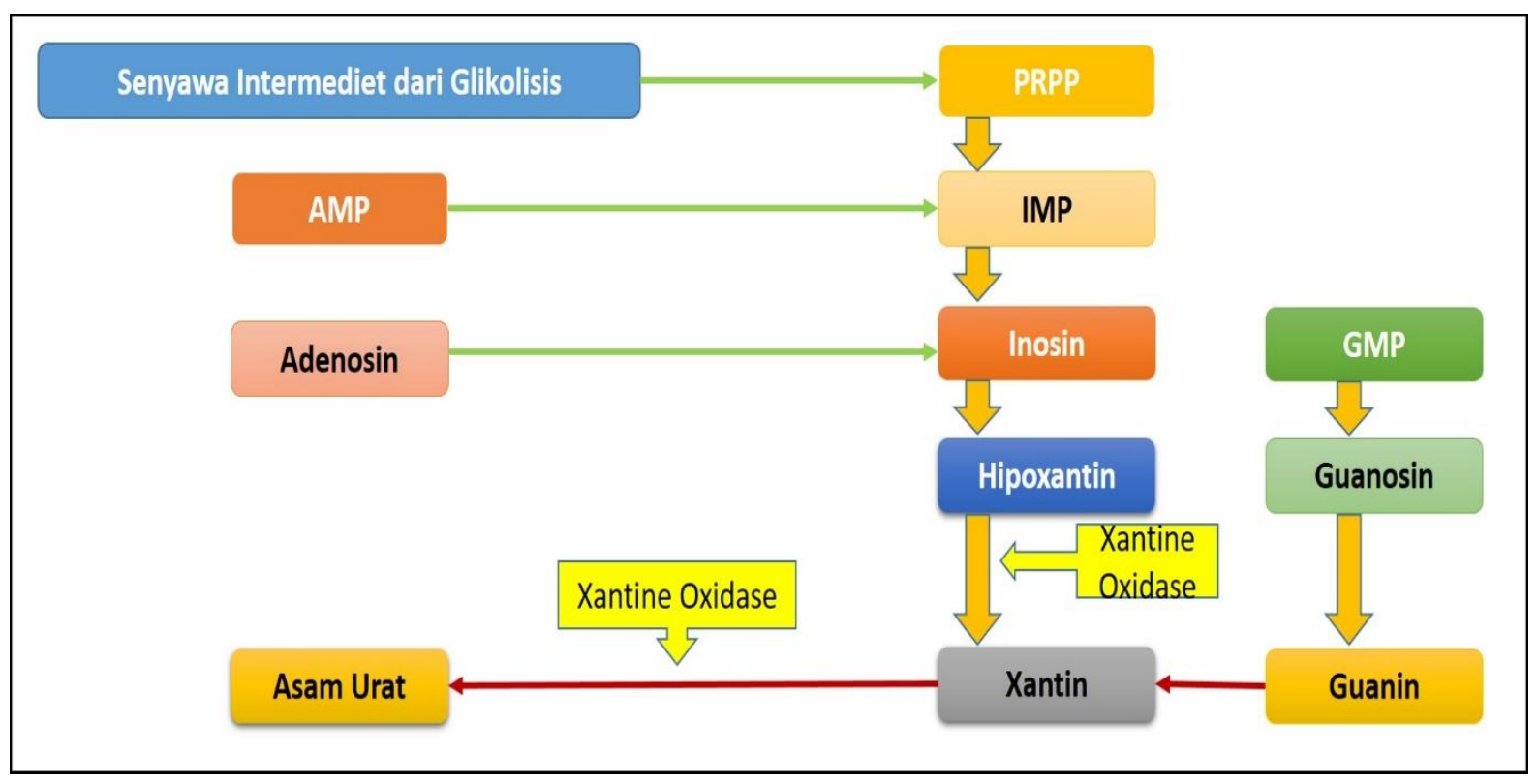

Gambar 2. Pembentukan Asam Urat Melalui Penguraian Basa Urin (diadaptasi dari Murray RK et al. 2014) $^{16}$

Asam klorogenat mempunyai aktivitas antioksidan, karena banyak mengandung gugus hidroksil (polifenol), sehingga asam klorogenat memberikan efek dalam menurunkan ROS, dengan cara menghambat kerja xantin oksidase dalam mengoksidasi xantin. ${ }^{5-7}$

\section{Malondialdehida}

Pada keadaaan kadar asam urat yang tinggi seperti pada penderita hiperurisemia dapat terjadi kerusakan pada membran sel akibat reaksi berantai peroksidase lipid. Makanan yang mengandung purin tinggi, akan mengaktivasi enzim xantin oksidase 20 kali lipat dari keadaan normal. Hal ini akan menyebabkan peningkatan radikal bebas dalam tubuh, seperti $\mathrm{O}_{2}^{-}$(superoksida) dan $\mathrm{OH}^{-}$ (radikal hidroksil). ${ }^{24}$

Radikal bebas akan menyerang asam lemak tak jenuh ganda atau Poly Unsaturated Fatty Acid (PUFA) yang merupakan penyusun membran sel, melalui pembentukan radikal karbon, radikal peroksil, dan peroksidasi lipid. ${ }^{16,24}$ Akibatnya rantai PUFA yang semula panjang akan terputus menjadi senyawa sederhana seperti hidrokarbon (pentana, etana) dan aldehid seperti malondialdehid (MDA). ${ }^{17,24}$ Mekanisme pembentukan MDA dapat dilihat pada Gambar 3. 


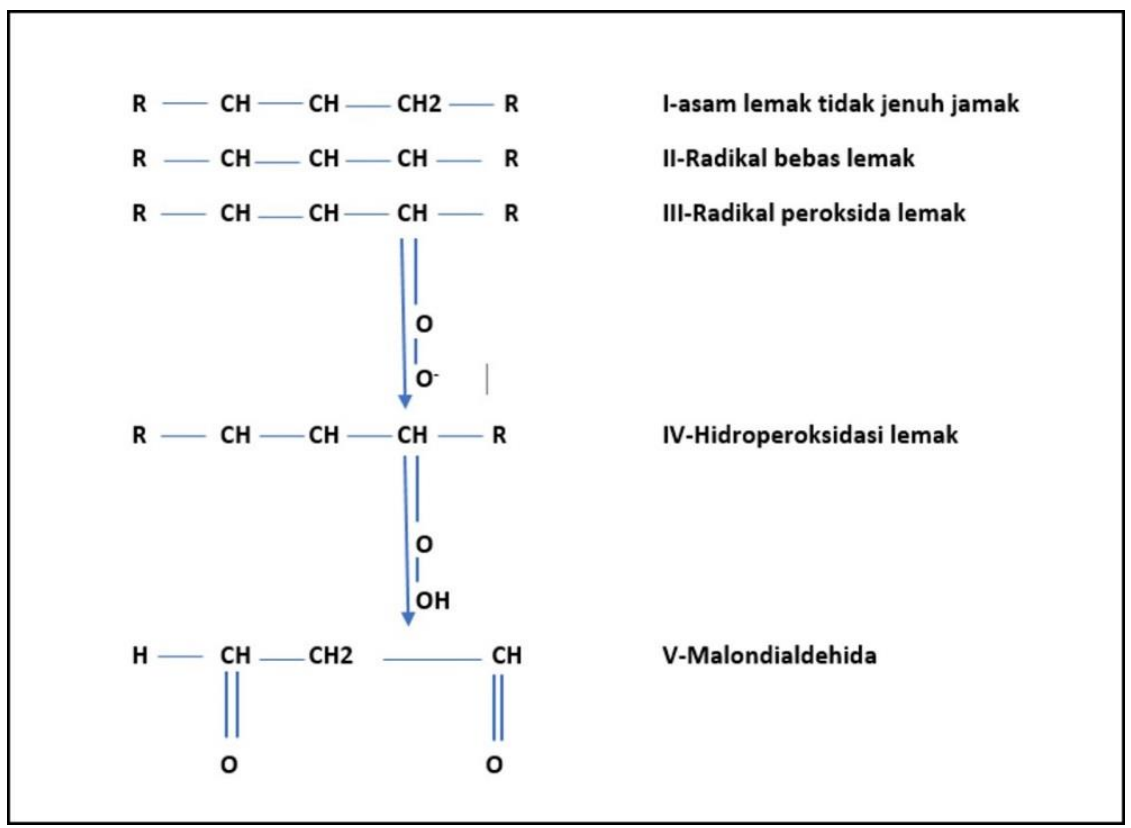

Gambar 3. Skema Pembentukan MDA dari PUFA (diadaptasi dari Belay et al 2009) ${ }^{24}$

\section{Penutup}

Peningkatan beban oksidatif (reactive oxygen species - ROS) dapat terjadi pada penderita hiperurisemia. Reactive oxygen species dapat menyebabkan peroksidasi lemak membentuk malondialdehid (MDA). Senyawa Asam klorogenat merupakan senyawa polifenol yang dapat berperan sebagai antioksidan. Senyawa ini bekerja dengan menghambat aktivitas enzim xantin oksidase. Dengan mengonsumsi herbal yang mengandung asam klorogenat tinggi dapat mengurangi peningkatan asam urat dan beban oksidatif dalam tubuh, sehingga dapat menurunkan kadar MDA di dalam darah.

\section{Daftar Pustaka}

1. Rukmana HR. Untung selangit dari agribisnis kopi. Yogyakarta: Lily Publisher; 2014.

2. Ayelign A, Sabally K. Determination of chlorogenic acids (CGA) in coffee beans using HPLC. Department of Post Harvest Management College of Agriculture and Veterinary Medicine Jimma University Ethiopia. 2013. hlm. 3-4.

3. Lelyana R. Pengaruh kopi terhadap kadar asam urat darah. Semarang : Program Pascasarjana Magister Ilmu Biomedik Universitas Diponegoro; 2008. Tesis.
4. Alam N, Yoon KN, Lee KR, Kim HY, Shin PG, Cheong JC, et al. Assessment of antioxydant and phenolic compound concentration as well as xanthine oxidase and tyrosinase inhibitory properties of different extracts of pleurotus citrinopileatus fruiting bodies. Mycobiology 2011;39(1). (diunduh 25 Mar 2017). Tersedia dari: http://www.ncbi.nlm. nih.gov/pmc/articles/PMC3385085/.

5. Koto FA, Kadri H, Rofinda ẐD. Pengaruh pemberian kopi instan oral terhadap kadar asam urat pada tikus wistar. Jurnal Kesehatan Andalas. 2014;3(3).

6. Farhaty N, Muchtaridi. Tinjauan kimia dan aspek farmakologi senyawa asam klorogenat pada biji kopi. Jurnal Farmaka Fakultas Farmasi Universitas Padjadjaran. 2014;4(1).

7. Putra TR. Hiperurisemia. Dalam: Setiati S, Sudoyo AW, Setiyohadi B, Simadibrata M, Syam AF, editor. Buku ajar ilmu penyakit dalam, Jilid III Edisi ke-V. Jakarta: Departemen Ilmu Penyakit Dalam Fakultas Kedokteran Universitas Indonesia; 2009. Halaman?

8. Meguro S, Hasumura $\mathrm{T}$, Hase $\mathrm{T}$. Coffeepolyphenols exert hypocholesterolemiceffects in zebrafish fed a high-cholesteroldiet. Nutr Metab. 2013 [diunduh 19 Jan 2018]. Tersedia dari: 
http://www.ncbi.nlm.nih.gov/pmc/articles /PMC 3871761/.

9. Kiyohara C, Kono S, Honjo S, Todoroki I, Sakurai Y, Nishiwaki M, et al. Inverse association between coffee drinking and serum uric acid concentrations in middleaged Japanese males. Br J Nutr. 1999 [diunduh 19 Mar 2017]. Tersedia dari: http://www.ncbi.nlm.nih. gov/pubmed/10743484.

10. Mangiwa S, Futwembun A, Awak PM. Kadar asam klorogenat (CGA) dalam biji kopi arabika (Coffea Arabica) asal Wamena, Papua. Jurnal Ilmiah Pendidikan Kimia 'Hidrogen' 2015;3(2):313-7.

11. Tamakoshi A, Lin Y, Kawado M, Yagyu $\mathrm{K}$, Kikuchi S, Iso H. Effect of coffee consumption on all-cause and total cancer mortality: Findings from the JACC study. European Journal of Epidemiology, 2011;26(4):285-93. [diunduh 20 Jul 2019]. Tersedia dari: https://doi.org/10.1007/s10654-0119548-7

12. Kaplan M. Norman, weber A. Michael. Hypertension essentials. $2^{\text {nd }} E d$. United States of America: Jones \& Barlett Publishers; 2010. P.2 - 95.

13. Mesas AE, Leon M, Rodrigues A, Lopez $\mathrm{G}$; The effect of coffee on blood pressure and cardiovascular disease in hypertensive individuals: a systematic review and metaanalysis. Am J Clin Nutr. 2011 Oct;94(4):1113-26.

14. Wierzejska R. Coffe cosumption and cardiovascular disease - Has the times comes to change dietary advice? A mini review.Pol. J. Food Nutr. Sci. 2016;66(1):5-10.

15. Dewajanti AM, Sumbayak EM, Neno MA. Uji aktivitas antioksidan infusa biji kopi arabika (Coffea arabica L): pengukuran kadar malondialdehid (MDA) pada tikus wistar (Rattus novergicus) hiperurisemia. J Kedokt Meditek 2018;25(64).

16. Murray RK, Granner DK, Mayer PA, Rodwell VM. Biokimia Harper edisi 29 Jakarta : Penerbit Buku Kedokteran EGC; 2014.

17. Crozier A, Clifford MN, Ashihara A. Plant secondary metabolites: occurrence, structure and role in the human diet. Oxford: Blackwell Publishing, 2006.
18. Monteiro, Mariana, Farah A, Perrone D, Luiz C. Trugo, Donangelo C. Chlorogenic acid compounds from coffee are differentially absorbed and metabolized in humans. The J of Nutrition. 2007;137: 2198-2201.

19. Farah, Adriana, Tomas De P, Daniel PM, Luiz CT, Peter RM. Chlorogenic acids and lactones in regular and waterdecaffeinated arabica coffees. J Agric. FoodChem. 2006; 54(2): 374-81.

20. Ayelign, Abebe dan Kebba S. Determination of chlorogenic acid. Am J of Research Communication. 2013;1(2):78-91.

21. Belay, Abebe, Gholap AV. Characterization and determination of chlorogenic acids (CGA) in coffee beans by UV-Vis spectroscopy. African J of Pure and Applied Chemistry. 2009;3(11): 23440.

22. Edward NL. Management of hyperuricaemia. Dalam: Koopman WJ, editor. Arthritis and allied condition: a textbook of rheumatology 14th ed. Philadelphia: Lippicott Williams \& Wilkins Baltimore Publishing; 2001.

23. Kelly WN, Wortmann RL. Crystalassociated synovitis: gout and hyperuricemia 5th ed. Philadelphia: WB Saunders; 1997.

24. Grotto D, Maria L, Valentini J, Paniz C, Schmitt G, Garcia $\mathrm{S}$ et al. Importance of the lipid peroxidation biomarkers and methodological aspects for malondialdehyde quantification. Química Nova. 2009;32(1):169-74. 